FACTA UNIVERSITATIS

Series: Linguistics and Literature Vol. 16, N² 2, 2018, pp. 181-194

https://doi.org/10.22190/FULL1802181I

Original Scientific Paper

\title{
IMPOLITENESS AND NARCISSISM: THE ANALYSIS OF CULPEPER'S IMPOLITENESS MODEL IN GONE WITH THE WIND
}

\author{
UDC 81’27:159.923
}

\author{
Katarina Ilić \\ University of Niš, Faculty of Philosophy, Niš, Serbia
}

\begin{abstract}
This paper provides a pragmatic analysis of the model of impoliteness in the light of narcissistic language, as many multidisciplinary studies have shown that personality dimensions, such as narcissism, may be related to specific language patterns. Narcissism is, therefore, commonly associated with the violation of polite language usage. The aim of the research is to identify impoliteness superstrategies, as provided by Jonathan Culpeper, in fictional conversations found in the screenplay of the epic movie Gone with the Wind. We conducted data analysis using conversation analysis and speech act theory. The results of the study will demonstrate whether there is a significant correlation between narcissistic personality disorder and impoliteness and what the quality of this relation is.
\end{abstract}

Key words: Culpeper's model of impoliteness, impoliteness superstrategies, narcissism, Gone with the Wind

\section{INTRODUCTION}

A socio-cultural view of politeness suggests that each society has a particular set of social norms consisting of more or less explicit rules that prescribe a certain behavior, and a positive evaluation arises when an action is in congruence with the norm. Such behavior is marked as polite. On the other hand, a negative evaluation, when an action is contrary to the norms, is called impoliteness (Fraser 1990: 220). Watts (2003: 4) provided a clear explanation of how the terms 'politeness' and 'impoliteness' should be used. Namely, it is important to separate the linguist definition of (im)politeness from its 'folk' or 'lay' interpretation. The former is known as 'second-order (im)politeness' while we use the term 'first-order politeness' to label the latter. Working within the framework of pragmatics, several researchers in the 1970s and 1980s postulated that politeness is a

Submitted July 23, 2018, accepted for publication October 11, 2018

Corresponding author: Katarina Ilić

University of Niš Faculty of Philosophy, English Department

E-mail: katarina.iiilic@gmail.com 
particular driving force in how people determine language choice and negotiate relational meaning (Locher 2012). This is how politeness became an important area of study. Several decades later, linguists started to investigate impoliteness alongside politeness.

The aim of this paper is to provide insight into impoliteness superstrategies in the light of narcissistic language, which is commonly associated with the violation of social norms characterized by polite language usage. There are reasons to believe that narcissism, like other personality dimensions, may be related to specific language patterns, as it is a stable trait associated with behavior in a variety of contexts (McGregor 2010: 6). Pragmatic analysis by which we examine the manifestation of impoliteness strategies in the narcissistic language will be performed on fictional conversations since it is believed that fictional characters embody interpersonal communication that can be found in the real world (Zou 2010: 160). We shall attempt to identify different impoliteness superstrategies, as proposed by Jonathan Culpeper, in fictional narcissistic characters and determine whether there is a significant correlation between this pragmatic model and narcissism as a personality disorder.

\section{THEORETICAL BACKGROUND}

\subsection{Theorizing Narcissism}

According to American Psychiatric Association (2000: 658, 659), individuals with narcissistic personality disorder have a grandiose sense of self-importance with a tendency to inflate their own accomplishments and underestimate the contributions of others. Furthermore, narcissism involves unwitting exploitation of other people and the expectation of great dedication on their part. These individuals often show signs of snobbish, disdainful, or patronizing attitudes. Bearing this in mind, it can be seen that such behavior is a social action which inevitably affects other members of society. Tamborski et al. (2012: 943) claim that a conceptualization of narcissism comprises two dimensions: an intrapersonal dimension of grandiosity and an interpersonal dimension of entitlement, where the former orients the narcissist toward maintaining an internal sense of self-importance whereas the latter deals with maintaining status vis-à-vis others. The same authors emphasize the link between narcissism and a variety of interpersonal strategies, such as displaying greater confidence in their responses to general knowledge questions, violating pro-social norms in order to protect their ego, responding aggressively to insults, vengeance seeking, etc. (Tamborski et al. 2012: 942, 943). The majority of these interpersonal strategies are manifested in narcissistic language use; thus this personality disorder can be examined in the light of several pragmatic theories.

To the present day, linguists have dealt with the relation between narcissistic personality and self-referential language use manifested in the exploitation of first-person singular personal pronouns (Pennebaker, et al. 2003; Tausczik \& Pennebaker 2010; Weintraub 1989), as well as with the analysis of directives as a speech act most commonly used in ineffective communication (Preston 2006: 13). Nevertheless, there have not been many attempts to relate narcissistic linguistic behavior to the impoliteness theory, even though impolite language use can be examined as one of the forms of narcissistic talk. 


\subsection{Theorizing (Im)politeness}

According to Culpeper (2011), linguistic politeness refers to linguistic or behavioral forms that are (conventionally) associated with contexts in which politeness attitudes are activated. It involves the use of expressions that are both contextually appropriate and positively evaluated by the target. Little work has been done on addressing communicative strategies which are attacking an interlocutor and causing disharmony, in other words, the strategies that are the opposite of politeness (Culpeper 1996: 349). It has been noticed that there are fewer theories focusing on impoliteness despite the fact that commentators are far more likely to comment on behavior which they perceived as impolite, rude, discourteous, obstreperous, bloodyminded, etc. (Watts 2003: 5).

This imbalance has recently been alleviated by the effort of two scholars, Jonathan Culpeper and Derek Bousfield, who laid the foundation for the systematic investigation of impoliteness in language. Bousfield (2008: 72), who analyzed impoliteness at the discourse level, defined it as an intentionally unmitigated or exacerbated face threatening act. His impoliteness model is developed around the already familiar theoretical grounding of Grice's theory of conversation and implicature, Goffman's notion of face, and a modified version of Brown and Levinson's politeness theory adapted for the analysis of impoliteness strategies (Bousfield 2008). Grice's theory of conversational implicature, as one of the pillars of linguistic impoliteness, basically means that "the conventional meaning of the words used will determine what is implicated, besides helping to determine what is said" (Grice 1989: 25). Grice further stipulates that each conversation is governed by the Cooperative Principle, which postulates that interactants, in their process of interpretation, work on the assumption that people adhere to four maxims: the maxims of quantity (be informative), quality (no falsehoods; no utterances that lack evidence), relation (be relevant), and manner (avoid obscurity or ambiguity, be brief and orderly). If interlocutors do not follow these maxims in the production of an utterance, which is frequently the case, their non-adherence results in additional meaning, the reasons of which should be interpreted (Locher 2012). Leech points out that politeness is then a motivation for nonadherence (Leech 1983: 80). Another crucial concept for understanding (im)politeness is "face". This notion, originally taken from Goffman but substantially developed by Brown and Levinson, is defined as "the public self-image that every member wants to claim for himself" (Brown and Levinson 1987: 311). It can be either negative or positive. The former expresses the want of every competent adult member that their actions be unimpeded by others while the latter represents the member's want to be ratified, understood, approved of, liked or admired. Certain verbal and non-verbal communication intrinsically threatens face, therefore, face-threatening acts (FTA) arise. They can threaten the addressee's negative or positive face (Brown and Levinson, 1987: 61, 312, 313).

Culpeper (1996: 355), the originator of the most notable model of impoliteness, also believes that the impoliteness phenomenon has developed around the concept of politeness, that is to say, it is the parasite of politeness. He originally defined impoliteness as the use of strategies that are designed to cause social disruption (Culpeper 1996: 350). Although it cannot be denied that impoliteness is intimately related to politeness, a more comprehensive research on this phenomenon has shown that impoliteness is no longer seen as a pragmatic failure or communicative dysfunction. It has gained a clearly systematic and strategic character (Garcia 2014: 62). As Culpeper argues (2011: 409), one obvious difference between politeness and impoliteness is that impoliteness has its own set of conventionalized 
impolite formulae. The most frequent impolite formulae type are insults, but also pointed criticisms/complaints, challenging or unpalatable questions and/or presuppositions, condescension, message enforcers, dismissals, silencers, threats, curses and ill-wishes, and non-supportive intrusions. According to Furman (2011: 6), Culpeper intends for his model to be used only to identify potentially impolite utterances, not to evaluate utterances as actually impolite, since the true evaluation of an utterance as impolite or mock-impolite is discursively constructed by the participants during a given interaction. Impoliteness superstrategies, designed to cause social disruption, were also related to power relations. There is an idea that a more powerful participant has more freedom to be impolite, leading to a prediction that impoliteness is more likely to occur in situations where there is an imbalance of social structural power (Culpeper 1996: 354, Keykhayee 2013: 354). Furthermore, that particular behavior can be considered impolite regardless of the speaker's intention. Namely, "impoliteness comes about when: (1) the speaker communicates faceattack intentionally, or (2) the hearer perceives and/or constructs behavior as intentionally face-attacking, or a combination of (1) and (2)" (Culpeper 2005:38). In his model of impoliteness, Culpeper elaborates on the superstrategies intended to produce disharmony between interlocutors in social interactions. What empowers this model is the variety of discourses built on real life data (Mohammed and Abbas 2015: 198). Culpeper's (1996: 356-358, 2005: 44) classification of impoliteness superstrategies is as follows:

a) Bald, on-record impoliteness: the face-threatening act is performed in a direct, clear, unambiguous and concise way in circumstances where face is not irrelevant or minimized. It occurs in any situation in which it is the speaker's intention to attack the hearer's face, and where there is much face at stake.

b) Positive impoliteness: Any action which damages the addressee's positive face wants. It includes disassociation or disinterest of speaker to hearer, seeking disagreement with the hearer, ignoring hearer, snubbing, the use of inappropriate identity markers, the use of taboo or abusive language.

c) Negative impoliteness: Any action which damages the addressee's positive face wants, any action which either frightens, scorns or ridicules the addressee (e.g. challenging). Belittling, invading the addressee's space - linguistically or physically. Associating the addressee with a negative aspect.

d) Sarcasm or mock politeness: The use of insincere politeness. Using implicature to express the opposite of what is said, i.e. 'have a good day' said sarcastically, within a confrontational context where the sentiment is not genuinely wished for.

e) Withhold politeness: Remaining silent when politeness is expected, e.g. by refraining from saying 'Thank you' in situations where it is customary to do so.

\section{METHODS AND MATERIALS}

The basis of our qualitative analysis is the abovementioned realization of Culpeper's impoliteness superstrategies. The sample on which we conducted the research is the screenplay for the American epic romance movie Gone with the Wind (1939), adapted from Margaret Mitchell's novel of the same title. Fictional conversations in the literary world can be used for such an analysis since they are actually based on the conversations 
taking place in the real world, with characters who have their personalities, thoughts and psychological activities (Zou 2010: 160).

The book and the movie should be understood in the context of their historical and cultural placement, which is the American Civil War - and their heroine, Scarlett O'Hara, a young lady who does not fit the stereotyped Southern woman. She has been traditionally recognized as "narcissistic, shallow, dishonest, manipulative, amoral, and completely lacking in any capacity for self-reflection and for analysis of the emotional and psychological responses of others" (Spanbauer 2001). The analysis is built on Scarlett's interactions with Rhett Butler, her husband, as well as her subordinates, such as slaves, servants and the like.

The methodology tool used in the research is a combination of conversation analysis and speech act theory since the research is not limited to the locutionary act but also attempts to gain insight into implicit associations within an illocution.

\section{DATA ANALYSIS}

The analysis in the paper presents each category described above, which we illustrate by a number of examples from the sample. Not all of the categories are equally represented since some examples are clearly unambiguous while others are fuzzy, which is partially the result of the overlap between the categories. Also, some examples are focused on the content of the message while others relate to vocabulary and grammar. This heterogeneity is explained by the fact that impoliteness functions on different levels of discourse.

\subsection{Bald, on record impoliteness}

This superstrategy is employed when there is much face at risk and when a speaker intends to damage the hearer's face, and the impolite utterance will be performed directly and clearly (Bousfield 2008: 92). As in Brown and Levinson's strategy (1987), the FTA is performed as clearly and boldly as possible, but the difference is that Brown and Levinson's strategy is a politeness strategy in situations where the threat to the hearer's face is small (Culpeper 1996: 356.) Therefore, Culpeper uses the concept of the faceattack-act (FAA) in order to identify the face attack where there is a deliberate intention on the part of the speaker (Mullany and Stockwell 2010: 71). The majority of impolite conversations taking place in the movie are between the main narcissistic character, Scarlett O'Hara, and her unscrupulous yet seductive husband, Rhett Butler. In one provocative love scene, where the two characters are flirting in her living room, the following conversation is taking place:

Rhett: No...I don't think I will kiss you. (he releases Scarlett, to her embarrassment and rage) Although you need kissing - badly. That's what's wrong with you. You should be kissed - and often - and by someone who knows how.

Scarlett (piqued): And I suppose you think you are the proper person!

Rhett (judiciously): Mmm .... I might be .... if the right moment ever came....

Scarlett: You are a black-hearted, conceited varmint, and I don't know why I let you come to see me.

In this interaction, we can see that neither of the interlocutors takes each other's utterances kindly. The first two turns are characterized by Rhett's implicit commissive 
stating that he will not kiss Scarlett, which is met by Scarlett's assertive aimed at mocking and insulting the addressee. Here, Scarlett uses irony to undermine Rhett's comment, which is a common linguistic realization of off record strategies (Brown and Levinson, 1987: 316). The next two turns indicate the escalation of the verbal disagreement where Scarlett goes on record and openly attacks the addressee. The face-threatening act is directly performed with the usage of offensive vocabulary (lack-hearted, conceited varmint) which is intended to damage Rhett's face straightforwardly.

Another more obvious example of bald, on record impoliteness is taken from an interaction between Scarlett and Rhett when the two characters discuss the war situation in the American South and possible damages that could be caused on Scarlett's plantation, Tara. In this case, Scarlett threatens to kill Rhett several times, which shows the lack of her intention to save the hearer's face by insulting him openly:

Rhett: Good evening. Nice weather we're having. Prissy tells me you are planning on taking a trip.

Scarlett: If you make any jokes now, I'll kill you.

Upon arriving, Rhett tries to make a joke and alleviate an already gloomy atmosphere caused by the horrors of war. His representative is not received favorably by Scarlett. Instead of an expected comment on the weather, she responds with attacking the hearer's face directly. This reaction is in line with the characterization of a typical narcissist, who enjoys spreading and arousing negative emotions and often responds with a heated argument (Preston 2014: 7).

In one of the following sequences when Rhett is hypothesizing the possible damages made to Tara and the threats Scarlett might encounter in case she decides to go back there, she reacts in a similar way, as in the following:

Rhett: Tara has probably been burnt to the ground. The woods are full of stragglers from both armies. The least they'll do is take the horse away from you. And even though it isn't much of an animal, I did have a lot of trouble stealing it.

Scarlett (hysterically): I'm going home if I have to walk every step of the way! I'll kill you if you try to stop me! I will! I will! I will! I will!

(She bursts into hysterical tears and starts beating Rhett's chest with her fists.)

In these exchanges of harsh words, the interaction allows for a straightforward ascription of impoliteness, which is further supported by Scarlett's non-verbal reaction of beating Rhett's chest. There are more examples of Scarlett's outbursts of non-verbal violence which indicate a direct attack on the interlocutor's face. They are in accordance with the attributes of a typical narcissistic character whose interpersonal high level of entitlement allows this kind of verbal and non-verbal attacks.

\subsection{Positive Impoliteness}

The second category in Culpeper's overview of impoliteness is positive impoliteness, the examples of which are commonly encountered in the corpus. According to the author, this particular superstrategy is aimed at attacking the interactant's positive face (Culpeper 2005). As stated above, it involves disinterest of speaker to hearer, seeking disagreement, ignoring, snubbing, inappropriate identity markers, taboo or abusive language (Toddington 2015: 15). All of these characteristics appropriately describe a narcissistic personality such 
as that of Scarlett O'Hara, who exhibits a relatively low desire for interpersonal relatedness (Campbell et al. 2002: 359), and shows a lack of interest for the hearer, jeopardizing their positive face.

Scarlett's verbal and non-verbal behavior is characterized by a number of instances which manifest positive impoliteness, especially with the characters whose social status she finds lower than hers. In those instances, she often ignores the interactant and shows disinterest. Many of the impoliteness scenes present conversations between Scarlett and Mammy, Scarlett's childhood nurse who displays a protective role and keeps Scarlett in line. In one of them, Mammy advises Scarlett not to overeat in front of people as this shows bad manners:

Mammy (squares off): Ef yo' don't care whut folks says 'bout dis fambly, Ah does! Ah has tole you an' tole you dat you kin allus tell a lady by de way dat she eats in front o' folks lak a bird! An' Ah ain' aimin' fer you to go ter Mist' John Wilkes an' eat lak a fiel' nan' an' gobble lak a hawg.

Scarlett: Fiddle-dee-dee! (she picks up her parasol and goes toward the door) Ashley Wilkes told me he liked to see a girl with a healthy appetite.

Scarlett's ignorance is contained in her commonly repeated ironic byword "fiddledee-dee", which indicates that the interactant's comment is ignored and not taken into consideration. This verbal action is followed by a non-verbal act of ignorance, by which she stops the conversation which is not in her interest.

This impoliteness superstrategy is also encountered in the interactions between Scarlett and Rhett, such as the following:

Rhett (finally): So she stood by you, did she? How does it feel to have the woman you've wronged cloak your sins for you?

(She makes no comment)

Rhett: You're wondering if she knows all about you and Ashley. You're wondering if she did it just to save her face. You're thinking that she's a fool for doing it, even if it did save your hide.

Scarlett: $\underline{\text { I will not listen! }}$

In this excerpt, identifying impoliteness markers can be a difficult task since Scarlett's silence can be interpreted as both her intention to ignore Rhett's comment but also an inability to provide an appropriate response. Therefore, it is obvious that the speaker's intention determines whether an impoliteness superstrategy is used or not. However, Scarlett's intention cannot be clearly discerned in the excerpt. On the other hand, her last turn is a clear example of positive impoliteness as this commissive commits her to the action of not responding.

Another frequently encountered issue is the possibility to identify one utterance as more than one impoliteness superstrategy, as in the example below:

Rhett: The world is full of many things and many people ... and I shan't be lonely. I'll find comfort elsewhere.

Scarlett: That's fine! But I warn you, just in case you change your mind, that I intend to lock my door!

In this section, Scarlett's response to Rhett's commissive can be understood as the use of negative impoliteness as her reaction can be understood as a threat to the addressee. 
Another feasible interpretation is the utilization of positive impoliteness, since this sentence can be seen as seeking disagreement.

Both examples are in line with the behavior of a typical narcissist who corrects, dismisses or ignores the interlocutor's comments if they are not in agreement with the narcissist (Preston 2014: 5).

\subsection{Negative Impoliteness}

Negative impoliteness is characterized by frightening, scorning or ridiculing the other, invading the other's space and explicitly associating the other with a negative aspect (Keykhayee 2013: 354). It is said that narcissists, such as Scarlett, exaggeratedly use grandstanding “merit badges' to show their grandiosity (Preston 2014: 6), which finally results in belittling the addressee. There are a number of situations in which Scarlett's selfprojected grandiosity, achieved on account of the interlocutor, can be observed. Here, a reader can also notice examples of her patronizing attitude, which is, according to Culpeper (2011), by far the most frequent label of impoliteness, relating a narcissist to an abuse of power and lack of deference. A scene in a lumber mill owned by Scarlett depicts her superiority reflected in her stance and posture:

(The men stop in front of Scarlett, who is standing at the side of the building, in a doorway leading into the mill office. Her figure is silhouetted against the light behind her. She stands like a general, feet spread, her hands behind her, looking down at the line of men, hard and businesslike. Behind her stand a terrified Frank Kennedy and a horrified Ashley. In the course of the scene Ashley dejectedly leaves and goes back into the office. Gallegher approaches Scarlett.)

Apart from these non-verbal signs of her narcissism, the interaction she has with her second husband, Frank, verbally embodies her self-projected superiority with the application of a negative impoliteness superstrategy:

Frank: But, Scarlett, this isn't right and you know it! It's bad enough for a woman to be in business at all, but -

Scarlett (interrupting sharply): What are you complaining about? You never would have owned a mill if I hadn't taken things over.

This interaction contains an anomalous turn according to the norms of turn-taking as Scarlett sharply interrupts the addressee and does not wait for the transition relevance place by breaking the rules of conversational interaction. Furthermore, Frank's complaint about Scarlett being in business is not met by either acceptance or refusal, which would make a logical adjacency pair, but an attack. Therefore, this illocution intends to belittle the addressee and associate him with a negative aspect rather than ask a question. This example proves Preston's (2014: 7) assumption that narcissists think of themselves as heroes or heroines who have an exaggerated sense of self-importance, and believe that others cannot survive without their magnificent contributions.

The aspects of negative impoliteness can also be noticed in Scarlett's relationship with Ashley Wilkes, a man with whom she is obsessed. Therefore, this superstrategy is applied not only in case when Scarlett scorns a person, but generally as a character trait of a narcissistic personality: 
Ashley (looks up as Scarlett walks toward him): Scarlett, I don't like to interfere, but I do wish you'd let me hire free darkies instead of using convicts. I believe we could do better.

Scarlett: Why, their pay would break us! Convicts are dirt cheap. If we just give Gallegher a free hand with them them

Ashley (bitterly): A free hand! You know what that means? He'll starve them and whip

- Didn't you see them? Some of them are sick, underfed -

Scarlett (impatiently): Oh, Ashley, how you do run on! If I let you alone you'd be giving them chicken three times a day and tucking them to sleep with eiderdown quilts.

Ashley: Scarlett, I will not make money from the enforced labor and misery of others.

As can be seen in the example above, Scarlett tries to ridicule Ashley's kindness and empathy with slaves, which is another aspect of negative impoliteness. This effect is achieved by Scarlett's presupposition that slaves are not entitled to decent living conditions. The illocutionary force observed is belittling the addressee.

Negative impoliteness traits can also be observed in Scarlett's relationship with her middle sister, Suellen:

Suellen (cattily to Scarlett): How's Ashley today, Scarlett? He didn't seem to be paying much attention to you.

Scarlett (gives a little look around to be sure no one has heard and speaks in an enraged undertone): You mind your own business! You'll be lucky if you don't lose old Whisker-Face Kennedy.

(Scarlett is removing her shoes.)

Suellen (trembling with rage): You've been sweet on Ashley for months! And his engagement's going to be announced tonight. Pa said so this morning!

In this example, negative impoliteness is embodied in the usage of a directive by which Scarlett attempts to frighten the interlocutor. The perlocutionary effect of scorning and belittling the addressee is achieved since stage directions prove Suellen's rage.

All the interactions incorporating negative impoliteness are related to a narcissist's superior orientation according to which this kind of people are not able to relate to individuals as equals due to their lack of empathy (Preston 2014: 7).

\subsection{Sarcasm or Mock Politeness}

Culpeper (1996: 356) describes mock politeness as an FTA which is performed with the use of politeness strategies which are obviously insincere and thus remain polite only on the surface. Simply, mock-politeness means using insincere politeness. Therefore, it is used to avoid conflicts if the addressee does not discern the insincerity behind this superstrategy.

In the following example, Charles Hamilton, Scarlett's first husband, announces that it is a war time and that everybody will go to war:

Charles: But it's war, Miss O'Hara! And everybody's going off to enlist. They're going right away. I'm going, too!

Scarlett (thinking of Ashley): Everybody?

(She runs to the window and looks out, searching for Ashley. Charles follows her, but she pays scant attention to him.) 
Charles: Oh, Miss O'Hara, will you be sorry? To see us go, I mean?

Scarlett (sarcastically): I'll cry into my pillow every night.

(Charles, misunderstanding, takes her hand. Scarlett still searching through the window.)

The fact that Scarlett is not really concerned about Charles can be seen in stage directions where we can notice that she pays scant attention to him and responds sarcastically. However, she frames the entire interaction as amicable by expressing mock concern with a commissive. Charles' misunderstanding shows that Scarlett's comment was taken at face value and the implicature of her mock concern was not discerned. The perlocutionary effect of fostering solidarity is achieved.

Scarlett's mock politeness is revealed in an interaction with India in a similar fashion. Since India is her rival it is easy to conclude that her politeness is not genuine:

Scarlett: Why, India Wilkes, what a lovely dress!

Suellen: Perfectly lovely, darling!

Carreen: Just lovely!

Scarlett (not looking at the dress, but looking around for Ashley): I just can't take my eyes off it.

As in the previous example, the illocutionary act is the one of affiliation. An insight into Scarlett's genuine feelings of indifference to India's dress is provided by stage directions where the reader can discern her genuine interest. Scarlett's attempt to appear friendly is in accordance with the belief that narcissists are expected to look and behave in ways that are immediately perceived as positive (Back et al. 2010: 141).

In the following example, Scarlett's utterances also remain polite on the surface and yet stage directions indicate that the mock politeness superstrategy is utilized. Here, the interaction incorporates three participants - Scarlett, Ashley and Melanie, who is being welcomed to the house:

Melanie (advances toward them): Scarlett! I'm so glad to see you again!

Scarlett (gushing insincerely): Melanie Hamilton! What a surprise to run into you here! I hope you're going to stay a few days with us at least.

(During Scarlett's line Ashley has been tenderly adjusting the scarf over Melanie's shoulder - almost as if in caress. Scarlett watches, jealous and resentful.)

Throughout the remainder of the scene, Ashley grows increasingly embarrassed and annoyed at Scarlett's cattiness.)

Here, Scarlett frames the interaction as harmonious by greeting Melanie kindly. However, we can infer that her kindness is pretended as she is "gushing dishonestly". Furthermore, a reader can notice that she is "jealous and resentful" while Ashley is annoyed at her "cattiness". All these vocabulary choices employed in stage directions reveal the mock-politeness superstrategy in Scarlett's utterance.

A fair number of instances where the mock politeness superstrategy can be identified is in line with the idea that narcissists "do not care about others and employ sarcasm and practical jokes" (Munro et al. 2005: 53). Therefore, it is not surprising that Scarlett's talk is characterized by the employment of this impoliteness superstrategy. 


\subsection{Withhold Politeness}

Withholding politeness is the absence of politeness work where it would be expected (Culpeper 1996: 356). In other words, it is the decision not to utilize politeness strategies where such behavior is expected. The lack of response can be interpreted as either ignoring the hearer, which falls within positive impoliteness, or withholding politeness. Therefore, the final superstrategy can be considered the most complicated. Still, this behavior corresponds to the manners of a typical narcissist, which can be seen in the examples below.

In the following interaction Charles declares his love to Scarlett but her reaction is not as expected:

Charles (whispers in Scarlett's ear): Miss O'Hara, I love you!

(Scarlett looks at the food, shakes her head, distracted.)

Scarlett: I don't guess I'm as hungry as I thought.

In this interaction, an adequate adjacency pair would be statement/acknowledgement; however, Scarlett's acknowledgement is missing. An expected polite response is replaced by a comment on her hunger by which she avoids providing an appropriate answer. This, therefore, indicates that expected politeness is withheld.

There is another example in which Scarlett fails to react adequately:

Rhett's voice (thickly): Come in, Mrs. Butler.

Scarlett reacts in fright, pauses irresolutely, saying nothing.

Due to the expectation that the second member of the adjacency pair follows the first, the reader is logically awaiting Scarlett's response in this interaction. As in the previous example, a polite response is missing, which can be interpreted as withholding politeness.

A similar reaction can be observed in an interaction between Scarlett and Mammy, where Mammy is complaining about her back pain but gets no reaction from Scarlett.

Scarlett (very gaily): How you feeling this morning, Mammy?

Mammy: Well ... this mizry in mah back ain' so good.

(Scarlett, paying no attention to Mammy's complaints, starts to hum happily the first bars of "Ben Bolt.")

As the expected adjacency structuring is missing in this example, the turns can be characterized as impolite in this case as well.

In all three examples it was challenging to determine whether the lack of response indicates positive or withheld politeness, given that both superstrategies are characterized by similar reactions. In any case, dismissing or ignoring the interlocutor's comments describes the behavior of an exemplary narcissist (Preston 2014: 5).

\section{DISCUSSION AND CONCLUSIONS}

The main aim of this paper is to explore the relationship between impoliteness strategies as proposed by Culpeper $(1996,2005)$ and narcissistic personality disorder. The sample for conducting this research is literature-based. Namely, the portrayal of Scarlett O'Hara's character from the book and the movie of the same title, Gone with the 
Wind, is chosen as the subject of this study because her personality is traditionally interpreted as narcissistic.

The methodological framework utilized for the identification and examination of impoliteness superstrategies was a combination of conversation analysis and speech act theory, which complemented each other. The conversation analysis, primarily concerned with the assumption that the utterance of one turn projects the logical completion of the next, was primarily used for comprehending withheld politeness. Speech act theory provided deeper understanding of the illocutionary forces behind the heroine's acts.

The analysis has suggested that each impoliteness superstrategy can be identified in the corpus and the examples provided are only an illustration of a great number of instances in which Scarlett employs some forms of impolite behavior. A problem we encountered in the analysis is the differentiation between particular impoliteness superstrategies, especial positive impoliteness and withheld politeness, where Scarlett's silence can be interpreted as either ignoring the collocutor or withholding a polite reaction. Another observation pertaining to positive impoliteness is that Scarlett employs this particular superstrategy in conversations with her subordinates, such as slaves and servants, rather than Rhett, whom she considers her equal and who himself employs impoliteness superstrategies. Furthermore, the conversations between Scarlett and Rhett are characterized by an abundance of impoliteness superstrategies, where one follows the other in the same conversation. As the examples above have demonstrated, mockery is often intertwined with bald on record and other impoliteness superstrategies.

In conclusion, narcissism, as a personality disorder, and linguistic impoliteness are closely related, since it was not a challenging task to identify impoliteness superstrategies in the analyzed fictional character. However, the fictional environment implies over-emphasized personality traits of characters, which may not always be encountered in the real world. Also, the narrator filters how and what we learn about the characters (Culpeper and FernandezQuintanilla 2017: 6). Despite this limitation, the research has demonstrated that the model of impoliteness can be used for characterization in fictional dialogues.

\section{REFERENCES}

American Psychiatric Association, (2000), Diagnostic and Statistical Manual of Mental Disorders (4 ${ }^{\text {th }}$ ed.), Washington, DC, American Psychiatric Association.

Back, M.D., S.C. Schmukle and B. Egloff. (2010), "Why Are Narcissists so Charming at First Sight? Decoding the Narcissism-Popularity Link at Zero Acquaintance", Journal of Personality and Social Psychology Volume 98, No.1, pp. 132-145.

Bousfield, D., (2008), Impoliteness in Interaction., Amsterdam, John Benjamins.

Brown, P. and Levinson, S. C., (1987), Politeness: Some universals in language usage, Cambridge, Cambridge University Press.

Campbell, W.K., E.A. Rudich and C. Sedikides. (2002), "Narcissism, Self-Esteem, and the Positivity of SelfViews: Two Portraits of Self-Love", Personality and Social Psychology Bulletin ,Volume: 28 issue: 3, pp. 358-368.

Culpeper, J., (1996), "Towards an anatomy of impoliteness", Journal of Pragmatics, 25, pp. 349-367.

Culpeper, J., (2005), "Impoliteness and entertainment in the television quiz show: The Weakest Link", Journal of Politeness Research 1, pp. 35-72.

Culpeper, J., (2011), "Politeness and impoliteness", In: K. Aijmer and G. Andersen (eds.) Sociopragmatics, Handbooks of Pragmatics, Volume 5, pp. 391-436.

Culpeper, J. and C. Fernandez Quintanilla. (2017), "Fictional characterization", In: M. Locher and A. Jucker (eds.) Pragmatics of Fiction. Handbooks of Pragmatics, Volume 12 Available at: https://www.academia.edu/23318801/4._Fictional_characterisation 
Fraser, B., (1990), "Perspectives on Politeness", Journal of Pragmatics, 14(2), pp. 219-36.

Furman, M., (2012), "Impoliteness and Mock Impoliteness in Dom 2", presented at University of Chicago Slavic Forum. Available at: http://lucian.uchicago.edu/blogs/theslavicforum/files/2011/12 /SLAVICFORUM_2011_FURMAN_PUBLICATION_FINAL.pdf

Garcia, F. F., (2014), "Impoliteness, Pseudo-Politeness, Strategic Politeness? On the Nature of Communicative Behaviour in Electoral Debates", Círculo de Lingüística Aplicada a la Comunicación, 58/2014, pp. 60-89.

Grice, H. P., (1989), "Logic and Conversation", In P. Grice (ed.) Studies in the way of words, Cambridge, MA, Harvard University Press, pp. 22-40.

Keykhayee, M., (2013), "The Relationship of the Type and Number of Impoliteness Strategies Employed by Sistani Students with Addressee`s Power and Gender", International Journal of Basic Sciences \& Applied Research. Vol., 2 (4)/2013, pp. 352-361.

Leech, G. N., (1983), Principles of pragmatics, New York, NY, Longman.

Locher, M., (2012), "Politeness", In C.A. Chapelle (ed.) The Encyclopedia of Applied Linguistics. New Jersey, Wiley-Blackwell.

Tamborski, M., R.P. Brown and K. Chowning. (2012), "Self-serving bias or simply serving the self? Evidence for a dimensional approach to narcissism", Personality and Individual Differences 52 (2012), pp. 942-946.

McGregor, S.A., (2010), The Analysis of Personality through Language: Narcissism Predicts Use of ShameRelated Words in Narratives, BA thesis, University of Michigan, Michigan, United States.

Mohammed, H.N. and N.F. Abbas. (2015), "Pragmatics of Impoliteness and Rudeness", American International Journal of Social Science Vol. 4, No. 6, pp. 195-205.

Mullany, L. and P. Stockwell. (2010), Introducing English Language: A Resource Book for Students, Nottingham, Routledge.

Munro, D., M. Bore and D. Powis. (2005), "Personality Factors in Professional Ethical Behaviour: Studies of Empathy and Narcissism", Australian Journal of Psychology, Vol, 57, No.1, pp. 49-60.

Pennebaker, J. W., M.R. Mehl and K.G. Niederhoffer. (2003), "Psychological aspects of natural language use: Our words, our selves", Annual Review of Psychology, 54, pp. 547-577.

Preston, N. C., (2006), How to Communicate Effectively and Handle Difficult People, USA, Preston C. Ni Copyright Press.

Preston, N. C., (2014), How to Successfully Handle Narcissists, USA, Preston C. Ni Copyright Press.

Spanbauer, J.M., (2001), "Scarlett O'Hara as Feminist: The Contradictory Normalizing Force of Law and Culture", Law Text Culture, Volume 5, Issue 2. Available at: http://ro.uow.edu.au/ltc/vol5/iss2/3

Tausczik, Y. R. and J.W. Pennebaker. (2010), "The psychological meaning of words: LIWC and computerized text analysis methods", Journal of Language and Social Psychology, 29, pp. 24-54.

Toddington, R.S., (2015), Impoliteness as a vehicle for humour in dramatic discourse, PhD thesis, University of Central Lancashire, Preston, England.

Watts, R.J., (2003), Politeness, Cambridge, Cambridge University Press.

Weintraub, W., (1989), Verbal behavior in everyday life, New York, NY, Springer.

Zou, S., (2010), "Analysis of Fictional Conversations Based on Pragmatic Adaptation", Journal of Language Teaching and Research, Vol. 1, No. 2, pp. 160-166.

\section{RESOURCES}

Gone with the Wind, (1939) [film]. Directed by Victor FLEMING. USA: Selznick International Pictures and Metro-Goldwyn-Mayer

Mitchell, M., (1936), Gone with the Wind, New York, The Macmillan Company. 


\section{NEUČTIVOST I NARCISOIDNOST: ANALIZA KALPEPEROVOG MODELA NEUČTIVOSTI U FILMU PROHUJALO $S$ VIHOROM}

Ovaj rad sadrži pragmatičku analizu modela neučtivosti u svetlu jezika narcisoidnosti, jer su brojne multidisciplinarne studije pokazale da dimenzije ličnosti, poput narcisoidnosti, mogu biti povezane sa specifičnim jezičkim obrascima. Narcisoidnoste, stoga, dovodimo u vezu sa kršenjem normi učtivog jezika. Istraživanje ima za cilj da identifikuje Kalpeperove superstrategije neučtivosti u razgovorima iz scenarija za kultni film Prohujalo s vihorom. Do rezultata smo došli putem analize konverzacije $i$ teorije govornih činova. Rezultati istraživanja pokazuju da li postoji značajna korelacija između narcisoidnosti, kao poremećaja ličnosti, i neučtivosti, kao i kakav je kvalitet te relacije.

Ključne reči: Kalpeperov model neučtivosti, superstrategije neučtivosti, narcisoidnost, Prohujalo s vihorom 